\section{Loopholes exploited} in whaling regulation

Sir - When asked what he thought of Western civilization, Mahatma Gandhi is said to have replied: "That would be a good idea". Simmonds and Stroud ${ }^{1}$ ask the scientific community to support their call for a global sanctuary to protect whales from direct killing in all maritime waters; some of us think that, too, would be a good idea, especially as your correspondents appear to wish also to stop what the International Whaling Commission (IWC) quaintly calls "aboriginal subsistence whaling" as well as the much larger scale commercial and "scientific" kinds.

But we have to ask what exactly is this global sanctuary? After all, scientists consider themselves to be rigorous in such matters. Ireland has called for one covering all offshore waters, essentially those beyond national jurisdictions, and as part of a proposed package deal to end the enduring impasse between whaling and non-whaling countries. That I understand, but Simmonds and Stroud don't mean that. If they want a sanctuary to stop all commercial whaling everywhere, then one has already been agreed: it is called an indefinite moratorium, and it was agreed in 1982, coming into force in 1986 . The trouble is that under applicable international law there are loopholes that are ruthlessly exploited by Norway and Japan and effectively negate the 1982 decision. And Japan does not even honour the sanctuary declared in the Southern Ocean in 1994.

IWC decisions are also not applicable to countries that do not belong to the organization and, further, the IWC cannot prevent its member states walking out whenever they feel like it.

I wonder under what legal mechanism Simmonds and Stroud would wish to see their "global sanctuary" established and how would they propose that any declaration of it be made binding on all states? By the United Nations, perhaps?

The scientific community, to whom Simmonds' and Stroud's call is addressed, could instead better rest its support for whale conservation and protection on science. The IWC has agreed on the most thoroughly science-based, the most fully tested procedure for regulating use of a living marine resource that has ever been proposed; it is called the Revised Management Procedure (RMP) and it is extraordinarily precautionary in approach ${ }^{2}$. If applied to all whale species and stocks it would, considering their states and the conditions of past exploitation, give zero commercial quotas for nearly all of them, for many, many years to come. Non-zero quotas would emerge for minke whales, but most of those would be protected if Japan were persuaded to honour the Southern Ocean sanctuary, because that is where $80-90 \%$ of the world's minke whales live.

So for the scientific community the rational approach is (1) to secure the protection of Antarctic waters; (2) to apply the RMP elsewhere; (3) to complete the proposed Revised Management Scheme (which includes the RMP) so that there is convincing inspection and international control over all whaling, including — as protection against unlawful trade - a DNA database, to be held by the IWC, and containing information about every whale legally killed.

\section{Sidney J. Holt}

Podere il Falco,

06060 Ponticelli, $P G$, Italy

e-mail:sholt/0002218557@mcimail.com

1. Simmonds, M. \& Stroud, C. Nature 392, 541 (1998).

2. IWC The Revised Management Procedure (RMP) for Baleen Whales. Rep. int. Whal. Commn 44, 145-167 (1994).

\section{We aim to refresh science, not to rebel}

Sir - We appreciate your interest in spontaneous meetings organized by young postdocs (see Nature 392, 211; 1998), which demonstrates your interest in the growth and formation of scientists in their early years. You have drawn attention not only to a new initiative but also to some of the problems experienced by postdocs. As organizers of the First European Workshop on Cell Death, however, we fear that the tone of the leading article may open the door to misinterpretation. We should therefore like to clarify our position.

Our meeting is not a 'rebellion' but a different type of approach, which we believe is necessary in a rapidly developing field with more than 6,000 publications a year and only one official European meeting. It is not intended to be a competitor of meetings organized by established groups, but a complementary initiative, which we believe fits in the objective of the European Cell Death Organization (ECDO).

We would also like to acknowledge that the European School of Haematology/ ECDO awards scholarships to young scientists. Nevertheless, the organization of meetings in cheaper locations with longer discussion time will benefit science by facilitating exchange, confrontation of ideas and collaborations.

We hope that young European scientists will help to 'refresh' science rather than 'rebel' against it. Our intention is not to create a negative attitude, but to send out a positive signal by showing that it is feasible to organize an inexpensive workshop, where we will try to create an atmosphere of open and constructive discussion for the improvement of the field.

Vincenzo De Laurenzi

IDI-IRCCS, Biochemistry Laboratory,

University of Rome Tor Vergata,

00133 Rome, Italy

e-mail:delaurenzi@utovrm.it

Michael Hahne

Institut de Biochimie,

University of Lausanne,

Ch. des Boveresses 155,

Epalinges,

CH 1066 Switzerland

e-mail:Michael.Hahne@ib.unil.ch

Henning Walczak

Tumorimmunology Programme,

German Cancer Research Center,

In Neuenheimer Feld 280,

69120 Heidelberg,

Germany

e-mail:h.walczak@dkfz-heidelberg.de

Jan Paul Medema

Immunohematology and Bloodbank,

Leiden University Medical Center,

Albinusdreef2,

2333AA Leiden,

The Netherlands

e-mail:j.p.medema@

immunohematology.medfac.leidenuniv.nl

BSE coordinator should have been full-time job

Sir - In your article about the bovine spongiform encephalopathy (BSE) inquiry (Nature 392, 532-533; 1998), you comment on my view, expressed in 1991, that "the problem was so big that it needed a coordinator to take hold of the whole thing". You have, however, missed the essential point I was making, that the problem required a full-time coordinator.

As I expressed in a letter to Keith Meldrum, the Chief Veterinary Officer at that time, part of which you include in your article, I felt it was expecting too much of a group of people (the Spongiform Encephalopathy Advisory Committee headed by David Tyrrell) meeting every two months or so to coordinate the work on BSE.

At no time was I critical of Tyrrell, who I consider did an excellent job. Seven years later, I still hold the view that the appointment of a full-time coordinator, who really knew about spongiform encephalopathies, would have been valuable.

\section{F. Brown}

US Department of Agriculture,

Plum Island Animal Disease Center,

PO Box 848,

Greenport, New York 11944, USA 